\title{
Research on the Form and Construction Characteristics of Traditional Folk Houses in Southern Liaoning Region
}

\author{
Ying Hao, Liu Yujun* \\ School of architecture and art design, liaoning university of science and technology \\ Anshan, liaoning province, China, 114051
}

\begin{abstract}
Since the traditional folk houses in Southern Liaoning Region have a long history, there are various construction forms of traditional folk houses similarly, with rick research significance. This paper mainly starts from the introduction about the development background and current status of traditional folk houses in Southern Liaoning Region, and then while understanding the typical characteristics of individual construction form types as well as the traditional folk houses decoration art in the form and construction characteristics of traditional folk houses in Southern Liaoning Region, it puts forward the current problems in the traditional folk houses of Southern Liaoning Region and the value analysis of traditional folk houses in Southern Liaoning Region. It is hoped that through the thesis research, it can make a little effort in protecting the traditional folk houses of Southern Liaoning Region, and arouse people's protection awareness for the traditional folk houses in Southern Liaoning Region.
\end{abstract}

Keywords-Southern Liaoning Region; Traditional folk houses; Construction characteristics; Protection strategies

\section{DEVELOPMENT BACKGROUND AND CURRENT STATUS ON TRADITIONAL FOLK HOUSES IN SOUTHERN LIAONING REGION}

In the Encyclopedia of China, the definition of folk houses is: from the pre-Qin period, our country has uniformly called imperial houses and folk houses as palace; from Han Dynasty, palace mainly referred to the place where the emperor lived, and the place where kings and nobles lived was called as imperial houses. Up till the modern China, folk houses mainly referred to residences beyond the palace and local fiefdom. Our country is a big historical power with five thousands of history, and the quantity of folk houses is huge, and due to the long history and serious aging of folk houses, the research of traditional folk houses is optional only. Thus, the traditional folk houses studied in this paper refer to those that were handed down from Ming and Qing Dynasty with relatively complete preservation status and relatively obvious construction characteristics in Southern Liaoning Region.

\section{A. Development background of traditional folk houses in Southern Liaoning Region}

Southern Liaoning Region is located at the south of Liaoning Province (northern latitude: $38^{\circ} 43^{\prime}-41^{\circ} 38^{\prime}$, east longitude: $118^{\circ} 50^{\prime}-125^{\circ} 14^{\prime}$ ), and is in Liaotung Peninsula, and is next to Bohai Sea and Yellow Sea of our country; since it is in the warm temperate zone, it is typical continental monsoon climate; besides, due to the reason of many oceans around and the bigger influence of ocean, it simultaneously possesses the characteristics of oceanic climate. Due to the difference in annual precipitation, the typical folk houses in Western Liaoning Region mainly focus on shallow-vaulted roof, but in regions near coast of Southern Liaoning Region, the roof form for folk houses is mainly gabbled roof.

Since Southern Liaoning Region is located at Liaotung Peninsula, the general terrain is southern part higher than the northern part, and the height inclined to the ocean from the inland; there are mountains and hills distributed on the eastern and western sides, and in the middle, it is the flat area. The distinction of landform will cause the difference in local climate, and then influence the distribution and form of folk houses as well as the formation of construction characteristics. In Anhui where people live besides water and Tibet where plateau locates as well as Southern Liaoning Region, due to the difference in landform, the type and construction characteristics of folk houses are also different.

Southern Liaoning Region has a long history, and since Wei and Jin dynasties, minorities in Northeast China Region started to form, rise and develop; in order to expand the territory of its own country, they entered into Central Plains, Southern Liaoning Region became a hotly contested spot, and Southern Liaoning Region was successively embezzled by Xianbei and other national minorities for above thousands of years, and then generated the long and complicated historical cultural phenomenon. In Ming and Qing Dynasties, after the traditional culture of Southern Liaoning Region has experienced the long-term and curved development, it finally entered into a relatively stable development period, and in Ming and Qing Dynasty, "Jinzhou-Fuzhou-Haizhou-Gaizhou" Four Guards were called as fertile places, which can let us know the flourishing degree of "Jinzhou-Fuzhou-HaizhouGaizhou" four cities at that time, up till present, the relics of 
these four ancient cities still exist, to let people find those rich historical deposits.

In the history, the social culture development of China used to have a turning point, i.e., the outbreak of Opium War in 1840, which was the turning point for traditional folk houses of Southern Liaoning Region. Niuzhuang is the earliest opened port in Liaoning Region, and in 1861, Yingkou started to gradually replace Niuzhuang Opening Port, and the opening of Yingkou Port not only opens a window for Liaoning Region to explore the world, but also constantly accelerates the steps for the modernization of Southern Liaoning Region. Just because of this opportunity, in Southern Liaoning Land, modern western-style buildings constantly occur, and can compete with the original traditional buildings. Just like what shows at Niuzhuang Catholic Church and Yingkou Old Street, there is a transformation from the form of traditional folk houses to western-style buildings.

\section{B. Existing problems}

Changes to the resident population in the block where historical residents located

According to the display of investigation data, the population loss in Liaoning is relatively serious, and has presented a decrease trend; besides, the aging problems are serious, and highly educated young people are more inclined to outflow, forcing the local resident population of Southern Liaoning Region change gradually, and it mainly includes the relatively weak groups constituted by the elderly, impoverished person, etc. Along with the constant development of economy, more and more residential buildings with completed functions and completed infrastructures are gradually built, and original residents in local started to move from the previously old block.

\section{Transfer of economic center}

Along with the fast increase of economics in Liaoning Province, and the constant acceleration of modernized process, due to the restriction of the conditions about the historical block or town where traditional folk houses in Southern Liaoning Region located, it is impossible for them to keep up with the pace of time, and with the transfer of economic center for the city, the local economic conditions are more backward, which will further result in the local young workers working outside, so it is no doubt the source that generates all kinds of problems. This is fatal for the upgrading and protection of traditional folk houses.

\section{Aging of traditional folk houses and buildings}

Due to long-term bad repair, the structure of these traditional folk houses have been subject to degeneration, and the damaged parts cannot be maintained in time, and many traditional folk houses have different degrees of aging and damage. This is why the fast development of economy can make the construction function of traditional folk houses fail to meet the demand of modernized life, and the aging of traditional folk houses will cause the failure in improving the economic value of folk houses.
Imperfection of the surrounding basic supporting facilities

Being restricted by the local economic development level of Southern Liaoning Region, basic supporting facilities are incomplete. The setup of parking lot, the treatment of garbage, and other problems that are closely related to the lives of residents haven't been properly solved yet. When the basic supporting facilities of the block where folk houses locate cannot meet the use of residents, it will delay the vigor for the development of traditional folk houses in the region.

\section{FORM AND CONSTRUCTION CHARACTERISTICS OF TRADITIONAL FOLK HOUSES}

\section{A. Single construction form type characteristics}

\section{1) Single construction type \\ Traditional folk houses}

The traditional folk houses of Southern Liaoning Region are mainly distributed at the historical ancient cities reserved from Ming and Qing Dynasties or relatively remote villages and towns, and as per the identity status and social background about the master of folk houses, the form of traditional folk houses in Southern Liaoning Region is mainly focused on courtyard, besides, there are also quadrangle courtyard, threesection courtyard and other different courtyards, but common courtyards only have principal room and courtyard wall. The traditional folk houses can be systematically divided into villa, former residences of celebrities, common courtyards and village thatched cottage. In Southern Liaoning Region, Liaoyang Peng Mansion is the representative of villa, but in Youyan, there are relatively more common courtyards.

\section{Invasive western-style buildings}

Due to the reason that Yingkou opens harbors for commercial intercourse, Yingkou Old Street has become the passively opened product, and the opening result is many distinctive stuff brought thereby. At the two sides of the Old Street, it still reserves traditional folk houses with above hundred years of history. They not only have rich and diversified construction forms, but also show the beauty combining Chinese and western-styles, and can reflect the gradual blend of Eastern and Western cultures. The traditional folk houses reserved by Yingkou Old Street adopt cement for construction, and a big part thereof were created at the end of Qing Dynasty and the initial period of the Republic of China, and they are mostly two-layer buildings, and the construction styles are mostly western-style, with few Chinese-style.

Chinese and western-style combined modern folk houses and buildings

The occurrence of Xinhai Revolution brought "the second spring wind" to the modern civilization of Southern Liaoning Region, and being driven by such spring wind, the construction culture of traditional folk houses in Southern Liaoning Region started to turn to learning from western construction cultures, absorbed and integrated the essence of western construction cultures, so various cities in Southern Liaoning Region gradually emerged some Chinese and Western-style combined new type of buildings, which exerted a profound influence on 
the Chinese and Western construction culture exchange and study. In 1907, West Mountain Danish Hospital was built by Chinese American Ning Naisheng upon the appointment of Danish Foreign Evangelization Society. Black brick tile gabbled buildings are the integration of Western Europe buildings in 18th Century and Chinese ancient construction styles.

\section{2) Single construction composition \\ Roof form}

Due to the difference in annual precipitation, the traditional folk houses in Western Liaoning Region are mainly shallowvaulted roof, but in regions near coast in Southern Liaoning Region, the roof forms of folk houses are mainly gabbled roof. Since the cantilever beams on the two sides of gabbled roof are small and exquisite, the general decoration is at the port of eave rafter, and fly rafter is the punch line for gabbled roof to attract people's attention. Gabbled roof is generally used in buildings with relatively important position among rooms in folk houses.

\section{Wall type}

Walls are one of the important element constituting traditional folk houses, and the type of walls can be mainly classified into two types: the first type is periphery wall, podium and corner wall; the other type is gable wall, sill wall and face wall.

Periphery wall: In the historical development process of Northeast China Region, due to the influence of troublous social situation, the construction characteristics of folk houses in Southern Liaoning Region present quite obvious defensiveness. Then high periphery walls are built around folk houses, which can not only deepen the closure equipped for courtyard folk houses, but also reflect the introverted form characteristics of folk houses.

Podium: Podium is mainly used as the boundary line of inner garden, and connects with the second gate, so podium is made into an independent courtyard wall.

Corner wall: The wall that connects the principal room and the western and western sides of the wing rooms in traditional folk houses is called as corner wall, which mainly exerts the function of shielding and maintenance.

Gable wall: The maintenance wall exerting support function at the two sides of the house, and it is constituted by three parts, including the upper part, lower alkali and pediment.

Sill wall: Sill wall is the front eave for traditional folk houses or the wall below the post-eave wood decoration couch.

Face wall: Face wall is the central gallery core wall of folk houses, and it is the two brick walls built inside the two sides of gallery.

\section{Door and window form}

The form of gates in traditional folk houses is relatively rich, and can be mainly divided into two types, the wall gate and the house gate, of which the house gate mainly refers to the house-shaped brick gate, and the wall gate mainly includes brick leg gate, wooden plate gate, and single gate. In Southern Liaoning Region, the form of gate is mainly brick leg gate.
House-shaped brick gate: In the Northeast of China, it is commonly known as brick wall, and wing rooms are mostly set at the two sides. The gate building width is at least 3 spaces, and special mansions can realize 5-7 spaces.

Brick leg gate: 1 space of building width and the structural framework adopts pole-mounted girder erection, on-beam purlin supporting beam type wooden structure approach.

Second gate: One entrance is set in the middle of podium for traditional folk houses, and this entrance is the second gate, which mainly exerts the function of keeping out sight and dividing functional space.

Window: In most traditional folk houses, single or double leaf plank doors, and removable window forms are adopted. The workmanship isn't miscellaneous and even looks slightly clumsy, but it can better adapt to the cold regional climate characteristics of Northeast China Region during winter.

\section{B. Traditional folk houses decoration art}

\section{Decorative cylinder}

Decorative cylinder is right above the gate of traditional folk houses, and it is a wooden component used to lock the middle sill and the connecting sill, and it can connect all the relevant components. Some decorative cylinders are not caved, some are caved. There are various forms of decoration, and the contents are extremely rich.

\section{Lotus pendants}

Lotus pendants get its name from the flower caves on the bottom of wooden poles hanging in the midair. The decoration with lotus pendants can not only show the decoration effect, but also meet the using function through saving space. The patterns caved and decorated with Lotus pendant heads are various and abundant, and lotus blossom, palace lantern and other patterns are also adopted.

\section{Bearing stone}

In traditional folk houses, bearing stone is commonly called as gate pier, stunning gate stone, etc., and it mainly exerts the function of supporting the door frame, and since it will be carved into pillow or box shape, it is called as the bearing stone. The bearing stone can be divided into two types as per the model: the first one is drum type pier, and the other one is cuboid-shaped, and they are collectively called as box pier.

\section{VALUE ANALYSIS OF TRADITIONAL FOLK HOUSES IN SOUTHERN LIAONING REGION}

Although the traditional folk houses in Southern Liaoning Region merely use buildings to express their languages, they cannot only directly reflect the epitome of semi-colonial and semi-feudal society, but also objectively record the modern history of Southern Liaoning Region, with rich historical value. Southern Liaoning Region has a long history, and since Wei and Jin Dynasties, national minorities in the Northeast of China started to form, rise and develop, and they entered into Central Plains, in order to expand the territory of their own country, and Southern Liaoning Region became a hotly contested spot for them. Southern Liaoning Region was successively 
embezzled by Xianbei and other national minorities for above thousand years, so a long and complicated historical culture phenomenon was generated. The folk houses built and generated thereby can fully reflect the unique characteristics of Southern Liaoning Region. For instance, Youyan rural folk houses in Southern Liaoning Region highlighted the defensiveness in construction characteristics, and high courtyard walls were built around folk houses; besides, there were also defensive towers built at the four corners of courtyard walls, to facilitate the defense of foreign enemies. The historical value included in the traditional folk houses of Southern Liaoning Region can not only reflect the living environment at that time, but also record the current social changes, and the construction appearance can more directly express the complicated and fickle social environment at that time, and let our descendants feel those historical cultures through these traditional folk houses.

Culture is the unique phenomenon existed in human society, and it is not only the product of social practice, but also generated from social practice. Folk house culture is generated from people's daily life practice, and then designed by human subject, and expressed through the mode of folk house construction. In Southern Liaoning Region, Liaoning is located at the three provinces in the Northeast of China, and the climate is cold in winter; in the constant development process, in order to resist cold, heated brick bed is invented in traditional folk houses, and then gradually forms its own unique styles in the process of resisting cold and heating. Southern Liaoning Region is a region with many nationalities, and there are more national minorities, especially Man People; ancestors of Man People were originated from mountains and rivers, and the fishing, hunting and collection life have deeply rooted in the thinking mode of Man People, and influence the construction concept of folk houses. The folk custom of "it is auspicious to live near water, and abundant to live near mountain" is the reflection of Man People for respecting water, and mountain offering ancient customs. The aforementioned cultural characteristics of Southern Liaoning Region are fully reflected in traditional folk houses, and through traditional folk houses, people's understanding about the unique culture of Southern Liaoning Region can be expressed, so they have clear and unique individuality.

Southern Liaoning Region belongs to the old industrial area in China, and also the industrial region for the Central Southern of Liaoning since the reform and opening-up policy, and the industry drives the fast development of economy, and then traditional folk houses of Southern Liaoning Region are derived thereby, which is not only the achievement for the fast development of economy, but also the product of urban changes, and the economic value brought thereby mainly includes the resource value and potential use value borne by its own assets value. Through these traditional folk houses, create unique resources with urban characteristics of Southern Liaoning Region, which can not only make traditional folk houses become the cultural carrier that can improve the soft strength of cities, but also become the material foundation for promoting the economic development of Southern Liaoning Region. Through using the economic benefit brought by using this traditional folk houses to carry out tourism as well as the economic added value brought by historical culture value, Fuzhou Ancient City, Yingkou Xiongyue Ancient City of Dalian Wafangdian have become an ancient city of historical culture through protection and reconstruction, and it has formed a tourism city since then, and largely promoted the local economic development, and provided a place for people to search for the past historical traces.

\section{CONCLUSION}

Currently, since Southern Liaoning Region has a vast territory, there is certain difficulty for conducting field investigation comprehensively and systematically. Since the traditional folk houses in Southern Liaoning Region are influenced by both natural and cultural factors, the construction form and internal space of folk houses are relatively simple, and the aesthetic value of construction is single, and can be easily neglected by people. In the recent decades, along with the fast development of economy, the traditional houses in Southern Liaoning Region have been damaged due to the lack of protection. In the local field investigation process, I found out that, many valuable buildings were dismantled or subject to destructive transformation, which had brought a bigger difficulty for us to conduct research work. This paper is merely the periodic learning achievement, and since the restriction of my personal knowledge, the lack of life experience and the difficulty of investigation, it is hard to avoid slight bias about opinions, which might be not comprehensive enough and the thoughts are not profound enough; it is hoped that the followup researchers can timely criticize and give advices to me.

\section{REFERENCES}

[1] Hu Qiaomu. Encyclopedia of China [M]. Encyclopedia of China Publishing House, 1996.

[2] Jin Zhenggao. Research about the Traditional Folk houses and Living Culture in Northeast China Region [D]. Minzu University of China, 2005 .

[3] Li Zhitin. Comprehensive History of Northeast China Region, Zhongzhou Ancient Books Publishing House, 2003.

[4] Zhou Lijun. Folk Houses in Northeast China Region Northeast China Region Northeast China Region [M]. Beijing: China Architecture \& Building Press, 2009: 38-77. 